\title{
DIFERENȚIERI TERITORIALE ALE FERTILITĂȚII \\ ÎN PERIOADA INTERCENSITARĂ
}

Ecaterina GRIGORAŞ ${ }^{\odot}$, drd., cercetător științific,

Centrul de Cercetări Demografice al INCE, Republica Moldova

DOI: https://doi.org/10.36004/nier.cdr.2019.14-16

JEL Classification: J11, J13.

În prezenta lucrare sunt analizate tendințele principale în evoluţia fertilităţii și caracteristicile principale ale populației după numărul de copii născuți, inclusiv in funcție de mediul de reședință. Cercetarea are la bază datele de la Recensământul populației și al locuințelor din 2014 (RPL 2014), Recensământul populației din 2004 și statistica curentă. Analiza distribuției femeilor după numărul de copii născuți-vii și pe medii de reședință în perioada intercensitară, demonstrează tendințe de restructurare a fertilității și modificări ale comportamentului reproductiv în toate grupele de vârstă. Cele mai tinere generații înregistrează o creștere a ponderii femeilor care nu au născut nici un copil până la vârsta de 30 de ani și reducerea proporției femeilor care au dat naștere la trei și mai mulți copii. Totuși, cea mai înaltă pondere revine femeilor care au născut doi copii, atât în mediul urban cât și în mediul rural, ceea ce determină predominarea modelului de familie cu doi copii.

Cuvinte-cheie: fertilitate, perioada intercensitară, diferențieri teritoriale.

In this paper are analysed the main trends in fertility evolution and main characteristics of the population according to the number of children born, including by place of residence. The research is based on data from the Census of Population and Housing of 2014 (RPL 2014), the Census of Population of 2004 and current statistics. The analysis of the distribution of women by the number of live births and by place of residence during the intercensal period shows tendencies of restructuring fertility and changes in reproductive behavior in all age groups. The youngest generations have an increase in the share of women who have not given birth to a child until the age of 30 and a reduction in the proportion of women who have given birth to three and more children. However, the proportion of women who have given birth to two children is the highest, both in urban and rural areas, which determines the predominance of the family model with two children.

Key words: Fertility, intercensal period, territorial differentiation.

\section{Introducere}

Necesitatea organizării societății moderne impune cunoașterea efectivului și structurii populației după diverse caracteristici și în perioade intercensitare, a cărei realizare este condiționată de înregistrarea sistematică și completă a evenimentelor demografice în general și a nașterilor în special.

Deși înregistrarea civilă și sistemele statistice vitale sunt modalitățile preferate de a colecta date despre fertilitate, recensământul oferă informații valoroase despre fertilitate, mai ales în țările în care înregistrarea nașterilor este incompletă. Recensămintele populației prezintă cele mai extinse date statistice referitoare la caracteristicile sociodemografice și socioeconomice ale populației și oferă un set de date originale care nu înregistrează statistica curentă, astfel reprezentând puncte de reper importante pentru analiza comparativă a celor mai principali indicatori dintre două sau mai multe recensăminte.

Pentru Republica Moldova, studierea natalităţii în baza datelor Recensământului populaţiei și al locuințelor din 2014 (RPL 2014) prezintă o actualitate deosebită determinată de necesitatea unei estimări corecte a fertilității și formarea unor percepții clare cu privire la tendinţele principale

\footnotetext{
๑) Ecaterina Grigoraș, egrigoras88@gmail.com
} 
în evoluția acesteia pentru a dispune de dovezi bine fundamentate în procesul de elaborare și promovare a politicilor ce țin de populație și dezvoltare. Analiza comparativă a fertilității în profil teritorial a femeilor, în baza Recensămintelor din 2004 și 2014, oferă informații cu privire la schimbările intervenite în evoluția acestui fenomen demografic în perioada intercensitară și poate servi drept bază pentru evaluarea datelor înregistrate.

Analiza diferențierilor teritoriale în comportamentul fertilităţii pot furniza indici utili în înţelegerea comportamentului reproductiv și a schimbărilor demografice contemporane.

Demografii școlii structuraliste tind să considere diferențierile fertilității după mediul de reședință rural-urban doar ca o manifestare spațială a pașilor diferențiali ai schimbărilor structurale din societate [7]. În comparație cu mediul rural, traiul în mediul urban nu numai că asigură creșterea cheltuielilor financiare directe ale creșterii copiilor, ci și costuri de oportunitate, datorită numeroaselor căi de mobilitate socioeconomică. Acestea sunt asociate cu creșterea ocupării forței de muncă neagricole și a infrastructurii de învăţământ superior. Mai mult decât atât, economiile orașului sunt mai expuse la efectele negative ale încetinirii economice. Efectul urbanizării asupra structurii cost-risc este o parte integrantă a rolului urbanizării în tranziția fertilității [11].

Alți cercetători consideră însă diferențierile fertilității rural-urbane ca manifestări secundare în cadrul unui sistem de regiuni culturale omogene în care se răspândește declinul fertilității.

Societățile urbane sunt caracterizate de trăsături distincte care accelerează răspândirea de noi comportamente [15]. Prin conexiuni sociale, economice, de transport şi comunicaţii, societăţile urbane interacționează intens cu țările străine care sunt mai avansate în tranziția fertilității. Interacțiunea socială este intensificată și în orașe, întrucât afinitatea conduce la individualizarea, anonimizarea și diversificarea culturală a societăților. Aceasta combate vechile sisteme de control social (stabilirea de reguli, standarde în modificarea comportamentelor sociale), accelerează difuzarea de noi valori privind comportamentul reproductiv și sporește legitimitatea mijloacelor moderne de contracepție [3]. Față de locuitorii din mediul rural, cei din mediul urban sunt mai capabili să pună în aplicare preferințele privind numărul de copii dorit în familie, din cauza accesului îmbunătățit la serviciile de planificare familială.

Factorii culturali pot explica, de asemenea, variația fertilităţii urbane-rurale. Cercetarile au demonstrat că oamenii din mediul rural și din orașele mici păstrează atitudini și stiluri de viață tradiționale, cu orientarea către familiile numeroase și preferința pentru familiile extinse. Populația din orașele mici poate fi considerată, ca o subcultură „orientată spre familie” în cadrul unei țări [14, $10]$.

Subcultura ,orientată spre familie” formează un context normativ pentru care cuplurile să se bazeze atunci când iau diverse decizii. La rândul lor, orașele sunt locurile în care a început și s-a răspândit ,,a doua” tranziție demografică, de asemenea, ele rămân un punct forte al valorilor ,,postmoderne" $[9$, p. 32].

Anumite țări europene, cum ar fi Spania și Italia, au prezentat de ceva timp cel mai scăzut nivel de fertilitate, în timp ce rata natalităţii în țările din nordul și vestul Europei a rămas constant mai mare. Aceste diferențe naționale se explică prin modelele relativ simple, care se concentrează asupra sistemelor de protecție socială sau structurile familiale prea restrictive, accentuând gama complexă de variabile contextuale care pot contribui la diferențele istorice și geografice în fertilitate [11].

Deși este un studiu mai vechi, dar care își păstrează încă actualitatea, o constatare importantă a proiectului de fertilitate european "Princeton" a fost că declinul fertilității a urmat modele spațiale distincte în interiorul țărilor. De asemenea, a arătat că fertilitatea urbană (atât conjugală, cât și generală) a fost mai mică decât fertilitatea din mediul rural înainte de tranziţia demografică, iar în timpul tranziţiei a scăzut mai devreme și mai rapid [6]. Mediul urban-rural înregistrează diferențe semnificative ale fertilității, ratele de fertilitate sunt percepute a fi semnificativ mai mici în mediul urban și mai înalte în mediul rural (în Franța, Italia, Estonia, Germania de Vest, Țările de Jos, Austria și Polonia, Danemarca, Finlanda, Norvegia și Suedia, 
SUA). Studiile europene demonstrează că fertilitatea suburbană contemporană continuă să fie mai mare decât în mediul urban și, în unele cazuri, chiar mai mare decât în mediul rural. Kulu și colaboratorii săi arată că în țările nordice rata fertilității în suburbiile orașelor și orașelor mici au crescut aproape ca cele din mediul rural. Este interesant de observat că diferențele nivelului fertilității dintre mediul urban și cel rural au existat de mai mult timp, pe când diferențele în calendarul nașterii au apărut destul de recent. În consecință, amânarea nașterilor este mai pronunțată în orașele mai mari decât în localitățile mai mici $[9,6]$.

\section{Date și metode}

Studiul este realizat pentru perioada intercensitară în baza datelor Recensământului populației 2004 (RP 2004) și al RPL 2014, totodată presupune utilizarea metodelor clasice de analiză demografică a fertilității. În baza conectării datelor RPL 2014 cu statistica vitală referitoare la natalitate pentru anii 2013-2014 a fost calculat indicatorul rata totală a fertilității pentru populația totală, precum și în funcție de mediul de reședință.

\section{Rezultatele cercetării}

$\mathrm{Cu}$ toate că Republica Moldova ocupă un teritoriu relativ mic, se constată diferențieri semnificative în profil teritorial. Evident că cele mai importante diferențe se înregistrează între populația urbană și cea rurală.

Analiza comparativă a fertilității pe raioane în anul 2014 (Fig. 1.) demonstrează nivelul înalt al fertilității pentru unele raioane de la nordul țării: Fălești $(2,09)$, Șoldănești $(2,11)$ și în raioanele de la centru: Orhei $(2,04)$ și Nisporeni $(2,14)$, unde valorile RTF înregistrează mai mult de 2 copii per femeie de vârstă fertilă.

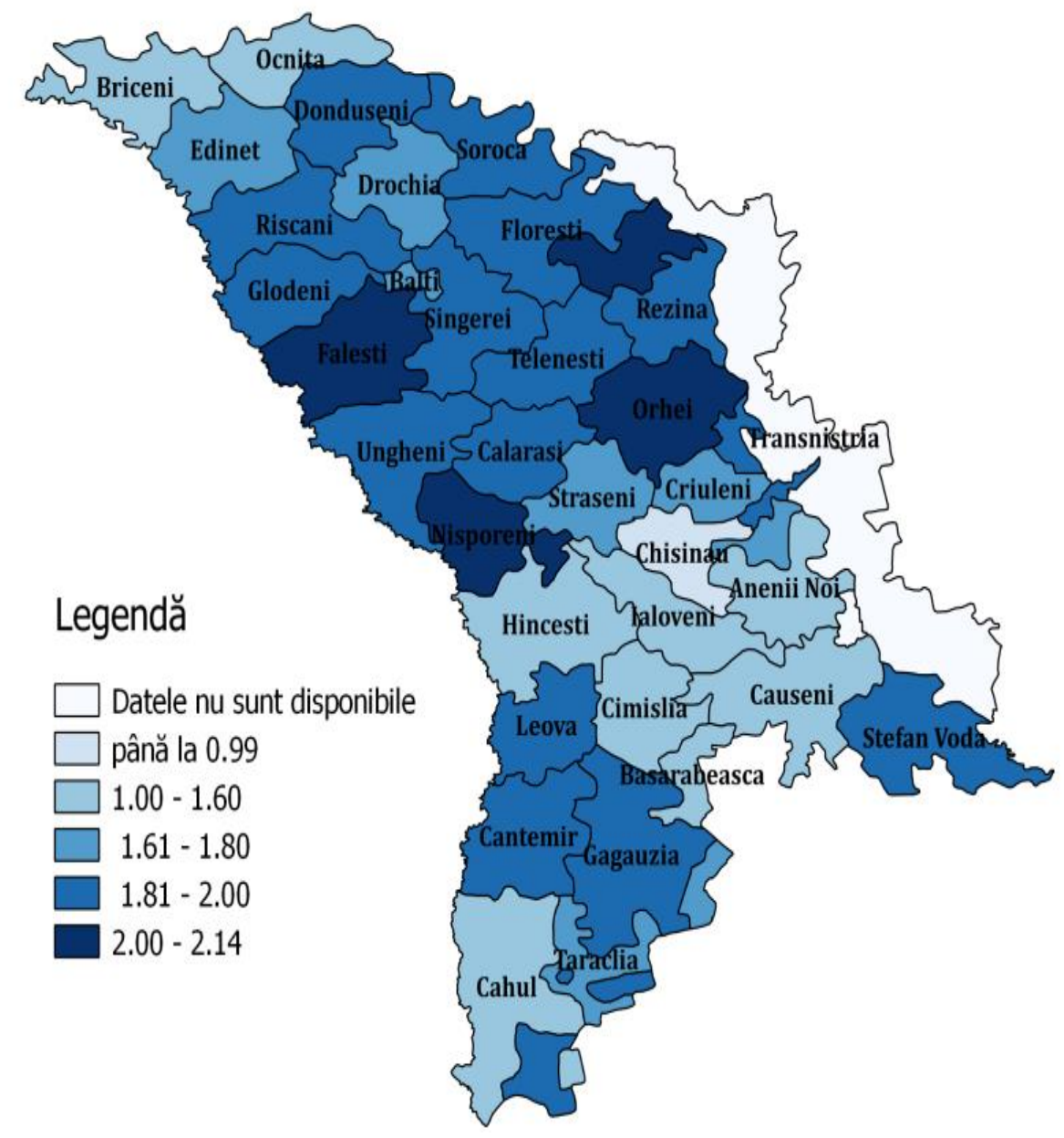

Figura 1. Rata totală de fertilitate (RTF) în profil teritorial, anul 2014

Sursa: Calculat de autori în baza datelor RPL 2014 şi statisticii vitale pentru anii 2013-2014 
RTF relativ înalte cuprinse între 1,81-2,0 copii per femeie de vârstă fertilă înregistrează raioanele din partea de nord a țării: Râșcani-1,83, Soroca-1,84, Dondușeni-1,87, Florești-1,91, Glodeni-1,93, Sângerei-2,00. Nivelul similar al fertilităţii se constată în raioanele de la centru: Călărași-1,81, Ungheni- 1,90, Telenești-1,96, Rezina-2,00 și cele din sudul republicii: Leova1,84,Cantemir-1,84, UTA Gagauzia-1,85, Ștefan Vodă-1,89.

Cele mai scăzute valori ale RTF (sub 1,5 copii per femeie de vârstă fertilă) se înregistrează în raioanele Briceni și Ocnița. În raioanele din centru: Hâncești, Ialoveni și Anenii Noi se înregistrează valori de sub 1,6 copii per femeie de vârstă fertilă. Asemenea valori sunt atribuite și raioanelor sudice: Căușeni, Cimișlia, Cahul și Basarabeasca.

Rate medii cuprinse între valorile 1,66-1,79 copii per femeie de vârstă fertilă înregistrează raioanele nordice: Edineț, Drochia și Bălți; raioanele de centru: Strășeni și Criuleni, iar la sud raionul Taraclia cu 1,61 copii per femeie de vârstă fertilă.

Municipiul Chișinău înregistrează cea mai mică RTF, aceasta fiind de 0,9 copii per femeie de vârstă fertilă, ceea ce este specific pentru orașele-capitale. Cercetările autohtone reliefează că nivelul scăzut al fertilităţii în capitală este determinat de o combinaţie de mai mulți factori: cauzele socioeconomice pentru amânarea nașterii unui copil, acordând prioritate educației și obținerii experienței pe piața muncii. În plus, subdezvoltarea serviciilor de educaţie extrafamilială și de îngrijire a copilului, existența stereotipurilor tradiționale privind rolurile de gen, nivelul înalt al educației și angajarea în câmpul muncii a femeilor contribuie la menținerea fertilităţii scăzute [16].

\section{Repartizarea femeilor după numărul de copii născuți}

Recensămintele populației oferă informații unice cu privire la repartizarea femeilor după numărul de copii născuţi-vii pe parcursul vieții astfel apare o posibilitate de a preciza descendența finală a diferitelor cohorte și de a crea o imagine complexă cu privire la nivelul de fertilitate.

Evident că în perioada între RP 2004 și RPL 2014 au apărut schimbări structurale semnificative, care, pe de o parte, sunt determinate de reducerea efectivului și a proporției generațiilor femeilor care s-au născut în anii înainte de cel de-al Doilea Război Mondial și în anii postbelici şi care au avut o fertilitate mai înaltă, iar pe de altă parte, de creșterea numărului şi proporției generațiilor tinere care s-au născut după anii '80 ai sec. XX și care se deosebesc prin fertilitatea mai scăzută.

Analiza comparativă a datelor demonstrează scăderea numărului mediu de copii care revine unei femei în vârstă de 15 ani și peste de la 1,9 în 2004 până la 1,63 în 2014 ca rezultat al scăderii RTF în perioada intercensitară. Este remarcabil faptul că acest indicator a scăzut mai mult în mediul rural - de la 2,2 până la 1,8 (-0,4), pe când în mediul urban - de la 1,4 la 1,3 (-0,1). Diminuarea mai semnificativă a numărului de copii per femeie poate fi observată și în grupurile de vârstă care sunt la etapa de încheiere a perioadei de reproducere (45-49 de ani). Astfel, în mediul rural numărul mediu de copii per femeie în acest grup de vârstă a scăzut de la 2,7 până la 2,22 (-0,48), iar în mediul urban- de la 1,9 până la 1,64 (-0,26). Descendența finală a femeilor la vârsta de 45-49 de ani, în anul 2014 a constituit 2,03 copii per femeie comparativ cu 2,3 în anul 2004 (Tabelul 1., Tabelul 2.).

De asemenea se atestă și o scădere a proporției femeilor care au dat naștere la trei și mai mulți copii - de la $26 \%$ la $21 \%$, în special la generațiile mai tinere, deși acest indicator ca descendență finală este destul de înalt. Astfel, la vârsta de 50-54 de ani 30\% din femei au declarat că au născut trei și mai mulți copii, cu 5\% mai puțin decât în anul 2004. ${ }^{34}$

\footnotetext{
${ }^{34}$ Datele RPL 2014 trebuie analizate cu precauție, o atenție deosebită fiind acordată calității datelor. În acest context, provoacă îndoieli datele referitoare la proporția crescută a femeilor de vârstele înaintate (60-64, 65-69, 70+), care pe parcursul vieții nu au născut nici un copil. Aceste generații la RP 2004 s-au referit la grupurile de vârstă care și-au încheiat perioada de reproducere $(50-54,55-59,60-64)$, iar proporția femeilor care nu au născut nici un copil în cadrul acestora a fost scăzută $(6 \%, 8 \%, 9 \%)$, care urma să se mențină la nivelul similar și la RPL 2014, în condițiile
} 
Tabelul 1. Repartizarea femeilor după numărul de copii născuți, anul 2004

\begin{tabular}{|c|c|c|c|c|c|c|c|c|c|}
\hline \multirow{2}{*}{ Vârsta } & \multicolumn{3}{|c|}{$\begin{array}{c}\text { Numărul mediu de copii } \\
\text { per femeie }\end{array}$} & \multicolumn{3}{c|}{$\begin{array}{c}\text { Au dat naștere la 3 copii și } \\
\text { mai mult (\%) }\end{array}$} & \multicolumn{3}{c|}{ Fără copii (\%) } \\
\cline { 2 - 10 } & Total & Urban & Rural & Total & Urban & Rural & Total & Urban & Rural \\
\hline Total & $\mathbf{1 , 9}$ & $\mathbf{1 , 4}$ & $\mathbf{2 , 2}$ & $\mathbf{2 6}$ & $\mathbf{1 2}$ & $\mathbf{3 4}$ & $\mathbf{2 2}$ & $\mathbf{2 5}$ & $\mathbf{2 0}$ \\
\hline $15-19$ & $\mathbf{0 , 0}$ & 0 & 0,1 & $\mathbf{0}$ & 0 & 0 & $\mathbf{9 6}$ & 98 & 94 \\
\hline $20-24$ & $\mathbf{0 , 4}$ & 0,3 & 0,6 & $\mathbf{1}$ & 0 & 1 & $\mathbf{6 5}$ & 77 & 54 \\
\hline $25-29$ & $\mathbf{1 , 1}$ & 0,8 & 1,4 & $\mathbf{6}$ & 2 & 9 & $\mathbf{2 7}$ & 36 & 20 \\
\hline $30-34$ & $\mathbf{1 , 7}$ & 1,3 & 1,9 & $\mathbf{1 5}$ & 5 & 21 & $\mathbf{1 2}$ & 18 & 8 \\
\hline $35-39$ & $\mathbf{2 , 0}$ & 1,6 & 2,3 & $\mathbf{2 4}$ & 10 & 33 & $\mathbf{7}$ & 9 & 5 \\
\hline $40-44$ & $\mathbf{2 , 2}$ & 1,8 & 2,5 & $\mathbf{3 0}$ & 14 & 42 & $\mathbf{6}$ & 7 & 4 \\
\hline $45-49$ & $\mathbf{2 , 3}$ & 1,9 & 2,7 & $\mathbf{3 4}$ & 17 & 47 & $\mathbf{6}$ & 7 & 5 \\
\hline $50-54$ & $\mathbf{2 , 4}$ & 1,9 & 2,7 & $\mathbf{3 5}$ & 18 & 48 & $\mathbf{6}$ & 7 & 6 \\
\hline $55-59$ & $\mathbf{2 , 4}$ & 1,8 & 2,8 & $\mathbf{3 4}$ & 16 & 47 & $\mathbf{8}$ & 8 & 7 \\
\hline $60-64$ & $\mathbf{2 , 5}$ & 1,9 & 2,9 & $\mathbf{3 9}$ & 19 & 50 & $\mathbf{9}$ & 9 & 9 \\
\hline $65-69$ & $\mathbf{2 , 6}$ & 1,9 & 3,1 & $\mathbf{4 1}$ & 20 & 52 & $\mathbf{1 0}$ & 10 & 11 \\
\hline $70+$ & $\mathbf{2 , 8}$ & 2,2 & 3,3 & $\mathbf{4 6}$ & 28 & 53 & $\mathbf{1 2}$ & 11 & 12 \\
\hline
\end{tabular}

Sursa: Calculat de autor în baza datelor RP 2004

Analizând descendența finală a femeilor în vârstă de 50-54 de ani (Fig. 2.) după numărul de copii născuți, constatăm că cea mai înaltă proporție revine femeilor care au dat naștere la doi copii cu o diferență nesemnificativă în perioada intercensitară: în anul $2004-41 \%$, în anul $2014-43,4 \%$, ceea ce confirmă orientarea spre numărul ideal de copii, care este doi copii [2]. Fiecare a cincea femeie din acest grup de vârstă a dat naștere la trei copii și către anul 2004 și către 2014.

Tabelul 2. Repartizarea femeilor după numărul de copii născuți, anul 2014

\begin{tabular}{|c|c|c|c|c|c|c|c|c|c|}
\hline \multirow{2}{*}{ Vârsta } & \multicolumn{3}{|c|}{$\begin{array}{c}\text { Numărul mediu de copii } \\
\text { per femeie }\end{array}$} & $\begin{array}{c}\text { Au dat naștere la 3 copii și } \\
\text { mai mult (\%) }\end{array}$ & \multicolumn{3}{c|}{ Fără copii (\%) } \\
\cline { 2 - 11 } & Total & Urban & Rural & Total & Urban & Rural & Total & Urban & Rural \\
\hline Total & $\mathbf{1 . 6 3}$ & $\mathbf{1 . 3}$ & $\mathbf{1 . 8}$ & $\mathbf{2 1}$ & $\mathbf{1 0}$ & $\mathbf{2 6}$ & $\mathbf{2 4}$ & $\mathbf{2 8}$ & $\mathbf{2 2}$ \\
\hline $15-19$ & $\mathbf{0 . 0 5}$ & 0.03 & 0.07 & $\mathbf{0}$ & 0 & 0 & $\mathbf{9 5}$ & 97 & 94 \\
\hline $20-24$ & $\mathbf{0 . 4 3}$ & 0.30 & 0.50 & $\mathbf{1}$ & 1 & 2 & $\mathbf{6 7}$ & 76 & 62 \\
\hline $25-29$ & $\mathbf{1 . 0 4}$ & 0.85 & 1.15 & $\mathbf{5}$ & 3 & 7 & $\mathbf{3 4}$ & 39 & 29 \\
\hline $30-34$ & $\mathbf{1 . 5 1}$ & 1.29 & 1.65 & $\mathbf{1 2}$ & 7 & 16 & $\mathbf{1 9}$ & 22 & 16 \\
\hline $35-39$ & $\mathbf{1 . 8 0}$ & 1.52 & 1.96 & $\mathbf{1 9}$ & 11 & 24 & $\mathbf{1 2}$ & 16 & 10 \\
\hline $40-44$ & $\mathbf{1 . 9 3}$ & 1.58 & 2.12 & $\mathbf{2 2}$ & 11 & 29 & $\mathbf{9}$ & 13 & 7 \\
\hline $45-49$ & $\mathbf{2 . 0 2}$ & 1.64 & 2.22 & $\mathbf{2 6}$ & 12 & 33 & $\mathbf{9}$ & 12 & 5 \\
\hline $50-54$ & $\mathbf{2 . 1 0}$ & 1.72 & 2.31 & $\mathbf{3 0}$ & 14 & 38 & $\mathbf{7}$ & 10 & 5 \\
\hline $55-59$ & $\mathbf{2 . 1 4}$ & 1.74 & 2.37 & $\mathbf{3 2}$ & 16 & 41 & $\mathbf{8}$ & 10 & 6 \\
\hline $60-64$ & $\mathbf{2 . 1 4}$ & 1.72 & 2.39 & $\mathbf{3 2}$ & 17 & 42 & $\mathbf{9}$ & 12 & 7 \\
\hline $65-69$ & $\mathbf{2 . 1 1}$ & 1.65 & 2.39 & $\mathbf{3 1}$ & 15 & 41 & $\mathbf{1 1}$ & 14 & 9 \\
\hline $70+$ & $\mathbf{2 . 3 4}$ & 1.71 & 2.61 & $\mathbf{3 6}$ & 18 & 44 & $\mathbf{1 4}$ & 17 & 13 \\
\hline
\end{tabular}

Sursa: Calculat de autor în baza datelor RPL 2014 


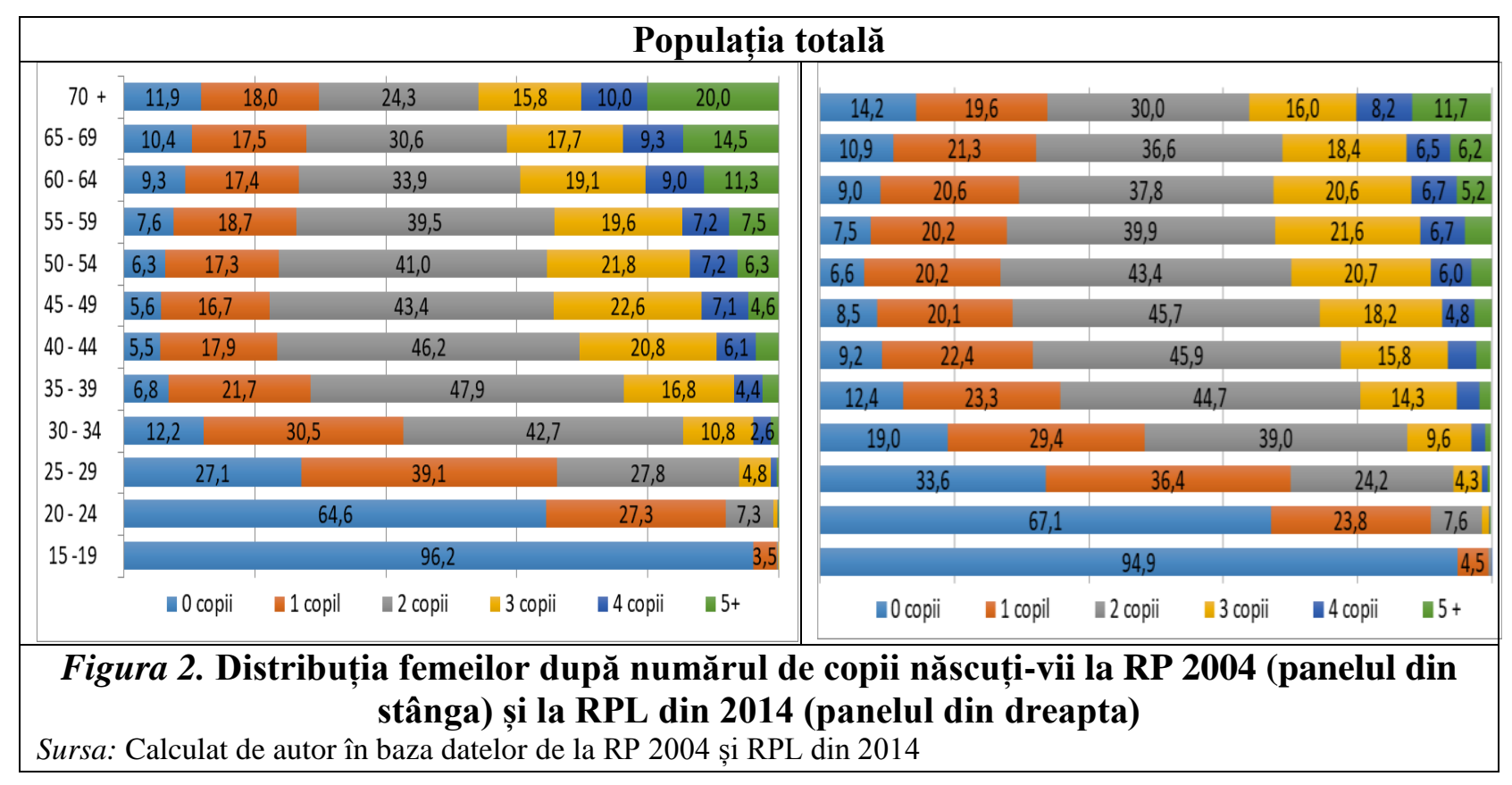

Proporția celor care au născut 4 copii a scăzut cu cca un procent - de la 7,2\% până la $6 \%$. De asemenea, tot mai puține femei au declarat nașterea a cinci și mai mulți copii.

Un interes deosebit prezintă datele cu privire la proporția femeilor care au născut doar un copil. În grupul de vârstă 35-39 de ani ponderea acestora în anul 2014 a constituit 23,3\%, iar în grupurile de vârstă mai mari acest indicator se reduce până la cca $20 \%$. Aceste date pun la îndoială unele informații referitoare la gradul înalt de infertilitate secundară în Republica Moldova [13].

În comparație cu alte ţări, în Republica Moldova ponderea femeilor care n-au născut nici un copil spre sfârşitul vârstei reproductive este mică şi, după cum demonstrează cercetările sociologice, refuzul benevol de a avea copii nu este acceptat de societate, majoritatea femeilor fiind orientate spre nașterea cel puțin a unui copil.

Specific Republicii Moldova este nașterea copilului la vârsta prematură (până la vârsta de 20 de ani). În perioada intercensitară situația nu înregistrează o dinamică pozitivă, în cel mai tânăr grup de vârstă 15-19 ani se constată o creștere cu un procent a proporției tinerilor care au născut copil/copii (în anul $2004-3,5 \%$, în 2014 - 4,5\%). Acest fapt indică necesitatea promovării active a măsurilor ce țin de prevenirea sarcinilor nedorite și consolidarea culturii contraceptive a tinerilor, introducerea în școli a programelor speciale de educație sexuală, acest fapt fiind argumentat în baza mai multor studii în domeniu [8].

Amânarea nașterilor spre vârstele mai mature a determinat creșterea proporției femeilor care nu au născut nici un copil până la vârsta de 30 de ani. Astfel, dacă în anul 2004 în grupul de vârstă de 25-29 ani - 27,1\% din femei încă nu au născut nici un copil, în anul 2014 acestea au constituit $33,6 \%$.

Se constată diferențe esențiale între populația urbană și cea rurală după numărul de copii născuți. Femeile de la sate, având o fertilitate mai înaltă, demonstrează o descendență finală crescută decât cele din orașe, precum și proporția mai înaltă a celor care au dat naștere la trei și mai mulţi copii.

Analiza distribuției femeilor după numărul de copii născuți pentru mediul urban demonstrează că printre cele mai importante schimbări în perioada intercensitară se înregistrează reducerea proporției femeilor care au născut patru și mai mulți copii, în special în rândurile generațiilor feminine mai tinere care s-au născut după anii `60 ai sec. XX.

În mediul urban, la RP 2004 (Fig. 3.) s-au constatat că mai mult de jumătate din femeile în vârstă de 40-44 ani și 45-49 ani au născut doi copii (51\%), respectiv un copil: 27,3\% și 24,7\%, trei 
copii și mai mult: $14,2 \%$ și 17,3\%. Nici un copil către vârsta indicată n-au născut 7\% dintre femei. La RPL 2014 se observă o scădere semnificativă a proporției femeilor care au născut mai mult de un copil, însă crește proporția femeilor care nu au născut nici un copil aproximativ în toate grupele de vârstă. Ponderea femeilor care au născut un copil a crescut până la $32 \%$ și respectiv $30 \%$, pentru grupele de vârstă de 40-44 și 45-49 de ani. Totodată, pentru anul 2014, se atestă o scădere a proporției femeilor în aceleași categorii de vârstă care au născut doi copii de cca 44\% și 48\%. Trei copii și mai mult au născut $8 \%$ și $9 \%$. În grupele de vârstă menționate nici un copil n-au născut $13 \%$ și respectiv $11,7 \%$, cca de două ori mai mult decât în anul 2004.

Totodată, se constată o creștere a proporției femeilor care încă nu au născut nici un copil în grupele de vârstă de 25-29, 30-34 și 35-39 ani.

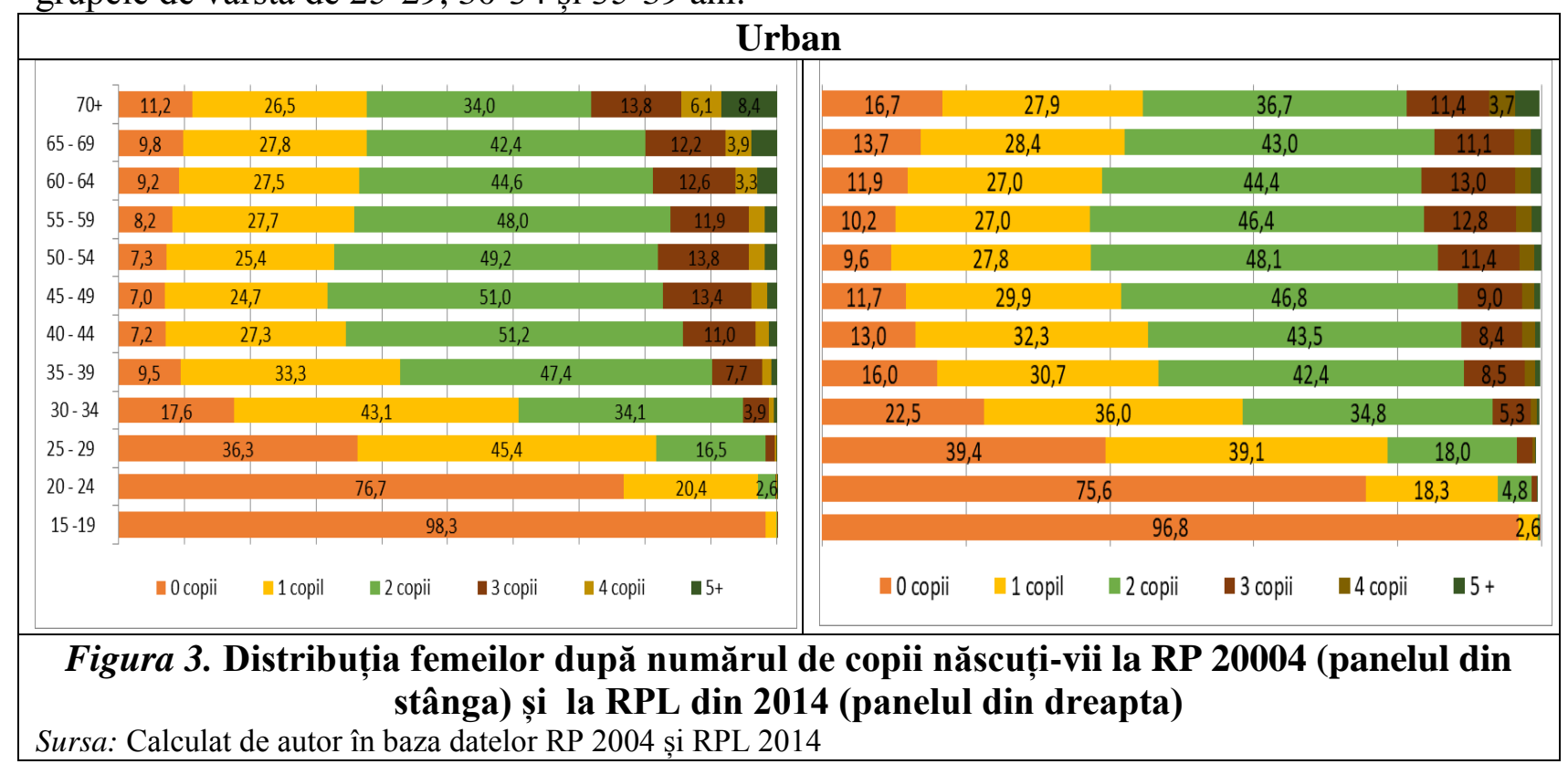

În distribuția femeilor din mediul rural (Fig. 4.) după numărul de copii născuți predomină proporția femeilor care au născut copii de rangul doi și trei. Astfel încât, cele mai multe din femeile în vârstă de 30-34 de ani au născut doi copii (48,8\%), 48,2\% în vârsta de 35-39 de ani și 47\% fac parte din grupa de vârstă de 40-44 ani, iar 46\% - din grupa de vârstă de 35-39 ani.

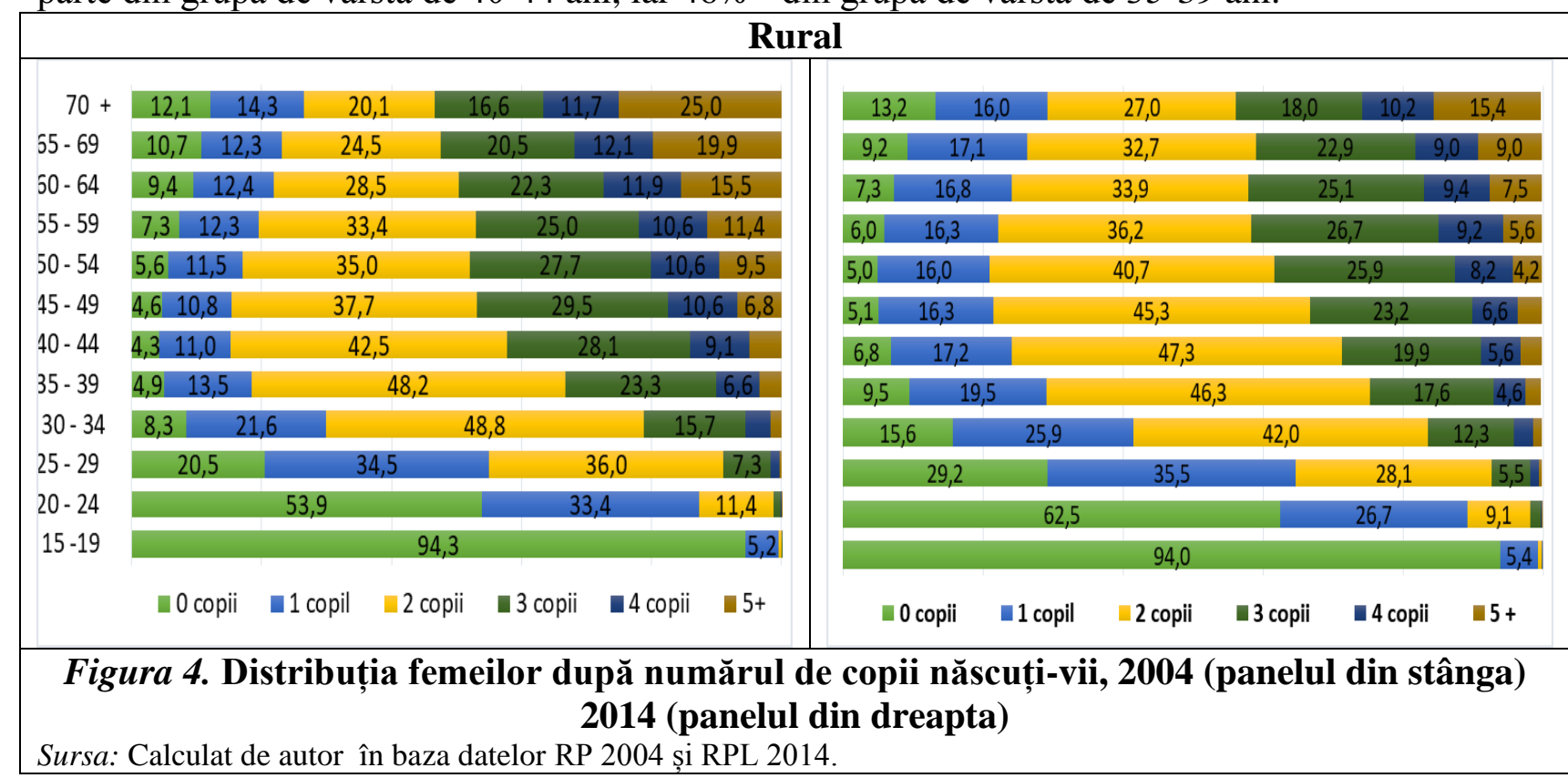


În mediul rural, la RP 2004 observăm că proporția femeilor în vârstă de 40-44 ani și 45-49 ani care au născut doi copii este de 43\% și 38\%, iar la RPL 2014, proporția acestora a crescut până la 45\% și 47\%. Respectiv un copil: 11\%, în timp ce în 2014 valorile cresc până la $17 \%$ și 15\%. Trei copii și mai mult: pentru 2004 înregistrează proporția femeilor de 28\% și 30\%, iar în 2014 valorile scad până la $17 \%$ și $15 \%$. Distribuția femeilor care nu au născut nici un copil către vârsta indicată este de 4\% și 5\%, iar în 2014 proporția acestora a crescut până la 7\%.

Mediul rural, la RPL din 2014 înregistrează o creștere a proporției femeilor care nu au născut nici un copil în grupele de vârstă de 20-24, 25-29 și 30-34 ani cu 9\%, iar în grupa de vârstă de 35-39 ani cu 5\%, în comparație cu anul 2004. În aceleași grupe de vârstă se observă și scăderea proporției femeilor care au născut copii de rangul unu. Totodată, la vârstele mai mari, care deja șiau încheiat perioada reproductivă, remarcăm modificări semnificative de scădere a ponderii femeilor care au născut cinci copii și mai mult.

Analiza distribuției femeilor după numărul de copii născuți-vii și pe medii de reședință în perioada intercensitară demonstrează tendințe de restructurare a fertilității și modificări ale comportamentului reproductiv în toate grupele de vârstă. Amânarea nașterilor spre vârstele mai mature în mediul rural a dus la creșterea proporției femeilor care nu au născut nici un copil către vârsta de 30 de ani. De asemenea, observăm o creștere a ponderii femeilor care au născut un copil și doi copii. În pofida diminuării proporției femeilor care au dat naștere la trei și mai mulţi copii, aceasta rămâne relativ înaltă, chiar și la vârstele tinere.

\section{Concluzii}

Distribuția femeilor după numărul de copii născuți-vii și pe medii de reședință în perioada intercensitară demonstrează tendinţe de restructurare a fertilității şi modificări ale comportamentului reproductiv la toate grupele de vârstă. Se constată o creștere a proporției femeilor care pe parcursul vieții reproductive au născut doar un copil și o scădere treptată a proporției femeilor care pe parcursul vieții au născut trei și mai mulți copii, în special la generațiile mai tinere. Totodată, ponderea femeilor care n-au născut nici un copil către sfârșitul perioadei reproductive este scăzută, astfel putem afirma că refuzul benevol de a avea copii nu este specific pentru Republica Moldova, normele sociale privind nașterea a cel puțin a unui copil fiind dominante. Amânarea nașterilor spre vârstele mai mature în mediul rural a dus la creșterea proporției femeilor care nu au născut nici un copil către vârsta de 30 de ani.

În structura populației feminine după numărul de copii născuți cea mai înaltă pondere revine femeilor care au născut doi copii, indiferent de mediul de reședință, ceea ce confirmă predominarea modelului de familie cu doi copii.

Fertilitatea descendentă a cohortelor feminine demonstrează că nivelul de fertilitate în Republica Moldova se menține în jur de 2 copii per femeie, acest indicator demonstrează riscul de subestimare a nivelului de fertilitate în baza RTF, în special în perioada de tranziție a fertilității de la modelul timpuriu la cel tardiv - proces observat în ultimele două decenii.

Astfel, comportamentul reproductiv este determinat de prevalența populației rurale în totalul populației (62\%), fiind unul mai tradiţional. Acest factor structural de asemenea determină și o viteză mai lentă în restructurarea calendarului naşterilor și menţinerea unui model timpuriu/intermediar al fertilităţii.

Totodată, cele mai tinere generații demonstrează modificarea comportamentului reproductiv, ceea ce se manifestă prin creșterea ponderii femeilor care nu au născut nici un copil până la 30 de ani și reducerea proporției femeilor care au dat naștere la trei și mai mulți copii.

\section{Bibliografie}

1. Gagauz O. Sarcina la vârsta adolescenței. INCE, Chişinău, 2015, 96 p.

2. Gagauz O., Buciuceanu-Vrabie M. Rolul profesional \& rolul parental: oportunități de echilibrare pentru femeia contemporană. Chişinău, 2011, p. 82. 
3. Republica Moldova. Studiu de indicatori multipli în cuiburi 2012. Centrul Naţional de Sănătate Publică, 2014.

4. Caldwell J. C. The Globalization of Fertility Behavior. Population and Development Review, 2001, nr. 27, p. 93-115.

5. Casterline J. B., Odden C. Trends in Inter-Birth Intervals in Developing Countries 19652014. Population and Development Review, 2016, nr. 42 (2), p. 173-184.

6. Castiglioni M., Dalla Z. and Loghi M. Planned and unplanned births and conceptions in Italy 1970-1995. European Journal of Population, 2001, nr. 17, p. 207-233.

7. George M., Eustaquio A. J., Cavenaghi S. Urbanization and fertility decline: Cashing in on structural change. IIED Working Paper. London: International Institute for Environment and Development, 2013.

8. Kulu H., Boyle P.J. High fertility in city suburbs: compositional or contextual effects? European Journal of Population, 2009, nr. 25(2), p. 157-174.

9. Kulu H., Boyle P. J., Andersson G. High suburban fertility: Evidence from four Northern European countries. Demographic research, 2010, Vol. 21, p. 915-944.

10. Lesthaeghe R., Neels K. From the first to the second demographic transition: an interpretation of the spatial continuity of demographic innovation in France, Belgium and Switzerland. European Journal of Population, 2002, nr. 18 (4), p. 325-360.

11. Mathias L. Fertility Decline in Urban and Rural Areas of Developing Countries. Population and Development Review, 2019, nr. 45 (2), p. 301-320.

12. Remi J., Christiaensen L. and Marina Gindelsky. Demography, urbanization anddevelopment: Rural push, urban pull and ... urban push? Journal of Urban Economics, 2017, nr. 98, p. 6-16.

13. Sharlin A. Urban-rural differences in fertility in Europe during the demographic transition. Coale A., Watkins S. The Decline of Fertility in Europe. Princeton: Princeton University Press, 2017, p. 234-260.

14. Sobotka T., Adigüzel F. Religiosity and spatial depographic differences in the Netherlands. University of Groningen, Groningen, 2002.

15. Dominique T. La ville et l'urbanisation dans les théories du changement démographique. Document de travail. Louvain-la-Neuve: Département des Sciences de la Population et du Développement, Université catholique de Louvain, 2000.

16. Бучучану-Врабие М. Детерминанты низкой рождаемости в столичном городе (на примере г. Кишинева). Демографія та соціальна економіка, 2010, nr. 1 (13), p. 124. 